\title{
WHITHER ISLAMIC LEGAL REASONING? The Law and Judicial Reasoning of The Religious Courts ${ }^{1}$
}

\author{
Ahmad Rofii \\ IAIN Syekh Nurjati - Cirebon, Indonesia | ahmadroff@gmail.com
}

\begin{abstract}
The article analyses the judicial reasoning employed by the religious courts in giving decisions on inheritance, particularly since the promulgation of the 1991 Compilation of Islamic Law. It seeks to examine whether these courts use Islamic legal reasoning. This paper argues that the structure of the courts' decisions is to be found in most Civil Law courts. It then offers three different approaches of reasoning employed by the religious courts in their decisions on inheritance: the use of the legislations particularly the Compilation as the sole source of deductive reasoning, the combination of the legislations and the Islamic sources which share the same implication, and the application of Islamic legal reasoning with the emphasis on the objectives of Islamic law (maqäsid al-shari ${ }^{-} a$ ) which does not contradict the legislations. Although Islamic legal reasoning is employed, in most cases the decisions are simple and straightforward.
\end{abstract}

Keywords: the Religious courts, the compilation of Islamic law, inheritance, Islamic legal reasoning.

\section{Introduction}

Modernity has brought serious challenges to Islamic legal system. The establishment of the modern state together with the colonialism has led to 'a systematic demolition of legal authority' in Islam. ${ }^{2}$ In

1 An earlier version of this article was presented at the Annual International Conference of Islamic Studies (AICIS) XIII in Mataram West Nusa Tenggara in November 2013. The author thanks the conference participants for their helpful comments.

2 Wael B. Hallaq, "Juristic Authority vs State Power: The Legal Crises of Modern Islam," Journal of Law and Religion, vol. 19 (2003-2004): p. 244. 
contrast with the practice of the pre-modern Islam, now it is the state which produces the legal authority for Muslim people. As the state takes over the control of legal doctrines, the 'ulamä' or fuqabä' (Muslim jurists) no longer enjoy their traditional status as the authoritative legal interpreters. Their privilege has been undermined by the state through the employment of professional lawyers who are educated in secular laws. ${ }^{3}$ South-East Asian states faced the similar challenges. ${ }^{4}$ The idea of modern nation-state is something new. It is largely based on the principle of secularism in which applicable law is a matter of the state determination and is manifested in the state's institutions. Nowadays, one finds Islamic law in state-defined forms in South-East Asia. The sovereignty of law comes from, instead of God's revelation through Muslim jurists, the state itself.

The significant transformation made by the modern state is likely to be apparent in the practices of courts. As a consequence of modern theories of nation-state, the courts are assumed to be the state institutions in which governmental powers and functions is vested. The legitimacy of modern Islamic courts is also derived from this doctrine. Accordingly, they articulate their function by applying the law on the basis of rules of law formulated by the state power.

In Indonesia, the existence of Islamic courts has been established by state legislations. During the Dutch colonial period, Islamic courts were regulated by Staatsblad No 152/1882 and Staatblad No 116 and 610 of 1937. In the post-revolutionary era, the government first promulgated the regulation No 45/1957. The Law on judicial power of 1970 and the Marriage Law of 1974 granted them more legitimacy. Then, with the enactment of the Law on Religious Justice in 1989, as amended by Law No 3/2006 and later by Law No 50/2009, their jurisdiction was widened. In addition, their power to execute the decisions has been recognized. The fact is that since 1980s there have been improvements in this judicial institution particularly in terms of the qualifications of judges and procedural matters. The judges as required by Law of Religious Judiciary must have a university degree either in syariab or general law. In addition, the law also sets condition for the graduate with general law degree that he or she should master

3 Ibid.; Ann Elizabeth Mayer, "Islam and the State," Cardozo Law Review, vol. 12 (19901991): p. 1015.

${ }^{4}$ See, e.g., M. B. Hooker, Islamic Law in South-East Asia (Kuala Lumpur: Harvard University Press, 1984), p. 36. 
Islamic law. Interestingly, regardless the required knowledge in Islamic law (here also includes classical Islamic family law), in deciding cases, they are provided with "Islamic codifications" such as Marriage Law and the Compilation of Islamic Law.

The reliance of the religious courts on those Islamic codifications, however, raises a question of whether this reliance could be read as an application of Islamic law in the traditional sense of the term. The fact that the Compilation, for instance, is based on, and derived from, authoritative literatures in Islamic law might indicate that it is an authentic expression of Indonesian version of Islamic family law. Nevertheless, this is likely to contradict the very nature of Islamic law (fiqh) as distinct from state law. While state law is defined by the government's arms, Islamic law is basically jurists' interpretations of the Islamic sources of law. Moreover, the religious courts' judges are government employees. They are bound by the government's ideology and policies. In this sense, they are required to decide cases in accordance with the principles and rules the state has laid down for them. It might be argued that the law on which the judges base their decisions is actually state-defined law.

This paper deals particularly with judicial reasoning applied in the religious courts of Indonesia. It seeks to examine whether these courts use Islamic legal reasoning, especially in inheritance cases. It argues that the religious courts' judges have to apply state laws using judicial methods which are common for other Indonesian courts. It becomes their enduring task to negotiate the state laws with Islamic legal reasoning.

\section{Islamic Courts and the Problem of Legal Reasoning}

In theory, there are two legal institutions which have functions of applying Islamic legal reasoning and articulating Islamic legal norms in a given case, namely fatw $\bar{a}$ and qad $\bar{a}$. These institutions have played a vital, robust role in maintaining the legitimacy of legal system facing with daily problems. Fatwa is an opinion on a point of religious law given by an authoritative figure or group in Muslim community. It is basically not binding in the sense that the questioner (mustafti) could avoid the opinion and seek another view that pleased him or her. Qada ', on the other hand, refers to an act of deciding dispute cases in 
accordance with God's law (ḥukm shar't), by which judges' decisions are binding to all parties. ${ }^{5}$

The religious nature of an Islamic court is embodied in the notion of application of divine law. Muslim writers said that the exercise of the court is a vital principle of religion, one of the noble acts of devotion, one of the important religious duties and a communal obligation in Islam (fard al-kifäyah). Judges are required to have such qualification as piety and knowledgeable of Islamic legal system and reasoning. They are obliged to decide cases in accordance with the rules of Islamic law. Does this mean that judges have to exercise legal reasoning accepted in Islamic legal methodology in deciding cases before them?

The term legal reasoning here refers to, as John Makdisi called, "rationality in a legal system". 6 It means a coherent set of legal principles and established methods which are exploited in order to modify, determine and reconstruct the laws within a legal system. In Islamic legal system, legal reasoning is generally used to refer to ijtihäd. It means the total endeavor made by a jurist to formulate rules of Islamic law. It is the third main source of Islamic law after al-Qur'an and Sunna. It manifests in various sources such as consensus $\left(i j m \bar{a}^{-}\right)$, analogy (qiyass), juristic preference (istibsän) and public interests (maslahab). The significance of this concept lies in its role in mediating revelation and reason in the body of Islamic law. ${ }^{7}$

The concept of ijtihad is in contrast with taqlid. The term taqlid means a submission to the authority or doctrines of a legal school. In this sense, the second category of mujtabid, namely mujtabid fi al-mażhab

\footnotetext{
5 The difference between what is called a rule of law according to judiciary and to religion, according to Mushţafā Aḥmad al-Zarqā̄, al-Madkhal al-Fiqh al-'Āmm (Damascus: Dār al-Qalam, 1998), vol. 1, pp. 67-69, constitutes the salient feature of Islamic law. See also Muhammad Hashim Kamali, Shari'ah Law: an Introduction (Oxford: Oneworld Publications, 2008), pp. 174-175.

' John Makdisi, "Formal Rationality in Islamic Law and the Common Law," Cleveland State Law Review, vol. 34 (1985-1986): p. 97.

${ }^{7}$ Mohammad Hashim Kamali, Principles of Islamic Jurisprudence, revised ed. (Cambridge: Cambridge Islamic Text Society, 1991), p. 366. See also Muḥammad ibn 'Alī ibn Muḥammad al-Shaukānī, Irshäd al-Fuhül ilā Tahquiq al-Haqq min Tlm al-Uṣ̂ul (Beirut: Dār al-Kutub al-Ilmiyyah, 1999), vol 2, pp. 205-206; Bernard Weiss, "Interpretation in Islamic Law: The Theory of Ijtibäd," The American Journal of Comparative Law, vol. 26, no. 2 (1990-1991): p. 200.
} 
(a person who exercises ijtibäd but is still bound by the school's principles or just acknowledges the imam's authority) is also regarded as pursuing taqlid. In a common usage, it relates to non-'ulamä' or laymen who according to this concept are dependent for their knowledge of Islamic law on "ulamā or mujtahid.

Islamic legal theory requires that muftis should be mujtahids. The authority of legal interpretation and reasoning is basically attached to them. Are judges also required to be mujtabids, so they must exercise their own reasoning? According to the classical doctrines of Shafi 1 , Hanbalī and some Hanafí, it was necessary for judges to be qualified as mujtabids. The majority of Hanafi, however, considered that nonmujtahids were allowed to be appointed as judges. The qualification of ijtihäd was not deemed necessary. It then became apparent in the course of history that the qualification of ijtihäd was only a matter of ideal. In practice, the medieval legal scholars unwillingly accepted the appointment of non-mujtahids.

In fact, before the period of the establishment of legal schools, as Hallaq pointed out, there were many judges who are mujtahids. They accordingly exercised their own reasoning for the judgments. Whenever they faced difficult cases, they would consult more competent mujtahids. Shafi'í (d. 204/820) even encouraged judges to look for legal advice from mufti-mujtahids authority. Thus, it is likely that the legal authority of judges at that time was dependent upon their competence on Islamic legal reasoning (ijtibäd). But, unlike judges, muftis were always mujtahids. Accordingly, they must be the authoritative figures to whom judges should seek the legal counsel. Islamic legal history shows that judges had largely consulted muftis' works in dealing with cases before the courts or they regularly asked muftis for legal advice. This practice is apparent in the fatwa literatures. Most documentations of fatwa are suggested to stem from questions asked by judges to muftis regarding the cases before them. ${ }^{10}$

\footnotetext{
${ }^{8}$ See, eg, Muḥammad ibn 'Alī ibn Muḥammad al-Shaukānī, Irshād al-Fuhūl, p. 239; Wael B. Hallaq, "Was the Gate of Ijtihad Closed?," International Journal of Middle East Studies, vol. 16, no. 1 (1984): pp. 3-41.

9 See, eg, Abū al-Ḥasan al-Māwardī, al-Ahkeàm al-Sultāniyyah wa al-Wilāyàt al-Diniyyah (Beirut: Dār al-Fikr, 1996), pp. 109-110; 'Abd al-Karīm Zaydān, Nizām al-Qậà' fì alIslàm, $2^{\text {nd }}$ ed. (Beirut: Mu'assasah al-Risālah, 1989), pp. 29-30.

10 Wael B. Hallaq, Authority, Continuity and Change in Islamic Law (Cambridge: Cambridge University Press, 2001), pp. 172-173.
} 
After the schools (mażhabs) were well-established and the doctrine of taqlid became prominent the practice of adjudication seems, as contemporary advocates of judicial constraint would say, merely to administer justice according to the rules of law. Hallaq clearly describes the function of judges,

[t]he locus of legal and hermeneutical creativity was thus the mufti whereas qadi applied the law much as a bureaucrat applies administrative rules. The mufti worked with textual and doctrinal evidence-the stuff of hermeneutic-but the qadi applied ready made solutions, reached by the mufti, to particular cases, after having heard the evidence. ${ }^{11}$

\section{The Religious Courts' Judges and the Procedural Unification}

Since the Dutch colonial era until the regime of New Order, Islamic courts were portrayed as having had suffered low prestige, unqualified judges and lack of well-established standard of adjudication. Describing the condition of the courts in that period, Daniel S Lev noticed that many people untrained, even in Islamic law it self, sitting as judges in Islamic courts. Consequently, Instead of being respected as religious leaders, the judges of Islamic courts were seen as merely as beambten (official) of the Dutch or local government. They were not well educated in Islamic law and were detached from religious authorities in the Muslim communities. ${ }^{12}$

\footnotetext{
${ }^{11}$ Hallaq, Authority, Continuity and Change, p. 76.

12 Daniel S. Lev, Islamic Courts in Indonesia: A Study in the Political Bases of Legal Institutions (Berkeley: University of California Press, 1972), pp. 11-13. Many Islamic organizations at that time had also noticed the same condition of the courts. This is not because of the lack of qualified ulama, but those ulama generally did not want to work under the Dutch Colonial administration. See Muhammad Hisyam, Caught between Three Fires: the Javanese Penghulu under the Dutch Colonial Administration 1882-1942 (Jakarta: INIS, 2001). In the post-revolutionary period, it was recognized that there were very few welltrained judges and some even decided cases with the ignorance of the law. There were attempts and pressures to appoint well-educated judges, for instance through the recruitment from university graduates, but it was far from success. Daniel S Lev argued that the procedures of the courts were unsystematic. The cases before the courts were mostly maintained by judges' common sense. Although there were improvements for example by the adoption to general courts' system, it was very limited. Moreover, this was exacerbated by the absence of adequate supervision of Islamic trial courts by appeal courts. Even in the appeal courts, there were frequently judgments decided on procedural errors. Lev, Islamic Courts, p. 93, and pp. 128-31.
} 
In the early 1980s, there was a policy of standardization of Islamic court judges introduced by the Department of Religious Affairs. It brought about significant changes in recruitment. The qualification of judges was one issue. With the policy of standardization Islamic court judges would hold a university degree and have knowledge of Islamic law as well as the national judicial system. ${ }^{13}$

The promulgation of the Law on Religious Justice in 1989 provided a robust basis for the improvement of the qualities of judges. This, in turn, would improve procedural standards of adjudication. This statute, however, should be read with a more general statute, namely the Law No 14 of 1970 on the Fundamental Provisions of Judicial Power. It will be obvious in the following paragraphs that Law of 1989 is maintained coherently with the Law of 1970. The amendment of Law of 1989 (Law No 3 of 2006 and Law No. 50 of 2009) is also enacted by reference to the amendment of Law of 1970 (as amended by Law No 4 of 2004 and Law No. 48 of 2009).

In terms of the qualities of judges, the statute provides provisions such as the requirements of judges, procedures of appointment, removal and supervision. This statute considers a judge as 'an officer who performs the duty of judicial power' (Article 11(1)). To be appointed as the courts' judge, one must meet some criteria. This includes a citizen of Indonesia, Muslim, devoted to God, loyal to Pancasila and the Constitution of 1945, civil servant and a degree in syari'ah or law knowledgeable of Islamic law (Article 13). The last two criteria were considered a significant change to the established requirements. As Cammack noted, 'under the 1882 statute only the court chairman was civil servant, and prior law did not specify any educational qualifications for judges, the vast majority of whom did not have university degrees'. ${ }^{14}$ These qualifications are not subject to substantial changes when the legislature passed Law No 3/2006 on the amendment of Law No 7/1989. In 2009, with the promulgation of the second amandment of Religious Judiciary Law, two points were added to the prior qualificatons, namely succeeding the professional education for judges and aged 25-40 years old.

13 Mark Cammack, "Islamic Law in Indonesia's New Order," The International and Comparative Law Quarterly, vol. 38 (1989): pp. 69-70.

14 Mark Cammack, "Indonesia's 1989 Religious Judicature Act: Islamization of Indonesia or Indonesianization of Islam?" Indonesia, vol. 63 (1997): p. 155 (citations omitted). 
Before holding the position, a judge must take an oath. In Law of 1989, the statements of oath consists of several pronouncements regarding the rejection of bribery and corruption, loyalty to Pancasila and the Constitution of 1945 and ethical conduct in dealing with cases before the court (Article 16). The amendment of this statute stipulates this in a simpler way. A judge is obliged to take an oath which is pronounced "[i]n the name of Allah, I swear that I will perform the judicial obligations for the best and justly, uphold the Constitution of 1945, enforce all regulations compliantly in accordance with the Constitution of 1945 and loyal to the country and nation". In both statues, judges, accordingly, are obliged to do justice not in accordance with Islamic law but with the Constitution and state laws.

In addition, Law No 3/2006 places a great emphasis on the 'one roof policy. According to Law No 7/1989, administrative supervision of Religious Court is under the Ministry of Religious Affairs. Now, all kinds of supervision are under the Supreme Court (Article 5). Regarding the appointment and removal of judges, now they are proposed by the head of Supreme Court with no reference to the Minister of Religious Affairs (Article 15). Meanwhile, in the previous law, Act of 1989 on religious court, such appointment and removal was performed by the President with proposal from the Minister of Religious Affairs and is based on the approval of the head of the Supreme Court,. All these changes restate the previous idea of judicial power as stipulated in Law No 4/2004.

In addition to the improvement of the qualities of judges (supposedly influenced by the previously explained changes), Law of 1989 also provides certain provisions concerning procedures. Chapter IV of the statute is devoted to the procedural law of the religious courts. This chapter was not subject for changes in Law of 2006. It consisted of three parts: general, trial on a dispute of marriage and costs. Interestingly, the chapter begins with the provision that Procedural Law applied in courts within Religious Justice is the Civil Procedural Law applied in courts within General Justice, except those which are specifically regulated in this Law' (Article 54). In the General Part, except that the courts are obliged in every decision to start with the statement of bismillah, there is no provision that is distinct from 
that of other courts according to Law No 14/970.15 By Law No 50 of 2009 , there are three provisions (60A-C) which are inserted between Article 60 and 61. Article 60A states that the judge must be accountable of her decisions in that she must give judicial reasonings for every decisions she made. Article $60 \mathrm{~B}$ and $\mathrm{C}$ requires the state to provide legal aids for justice seekers.

Concerning the court's decisions, the statute requires that every decision must contain not only the reasons and the basis but also certain articles and provisions of relevant regulations or the unwritten source of law which constitutes the basis of adjudication (Article 62(1)). This article provides the basic requirements of a decision. It demands that when deciding cases before the court, judges must take state regulations and/or unwritten law into consideration. The reference to statutory provisions in every judge's decision becomes inevitable. While state laws in this statute are obvious, what the unwritten law here means remains unclear. It may be any or all of adat or Muslim local customs or unlegislated Islamic law. ${ }^{16}$

The religious courts deliver decisions in a matter of a complaint (gugatan) against another Muslim in a dispute case and application (permohonan). In the elucidation of Article 60, the first type of decisions is called putusan (decision) and the second is penetapan (declaration). While the decision resolves the dispute and decides who wins the claim, the statement declares, for instance, the legality of a marriage performed before the promulgation of Marriage Law of 1974, the origins of a child (the elucidation of Article 49 (2)) and the validity of a talak divorce. From the courts' decisions and statements one can ask for appeal to the Religious High Court (Pengadilan Tinggi Agama) (Article 61). And, if he or she wishes to challenge the High Court's decisions, he or she could ask for cassation to the Supreme Court (Mabkamah Agung) (Article 63).

With the promulgation of Law on Religious Justice it is likely that the procedures of the religious courts have been improved. Likely, The changes made are taken as efforts to achieve the standards applied in

${ }^{15}$ Article 56 of Law of 1989 is comparable with Article 14 of Law of 1970, Article 57 with Article 4, Article 58 with Article 5, Article 59 with Article 17, Article 60 with Article 18, Article 61 with Article 19 and Article 62 with Article 23.

16 M.B. Hooker and Tim Lindsey, "Public Faces of Syariah in Contemporary Indonesia: Towards a National Mą̧bab?," Australian Journal of Asian Law, vol. 4 (2002): p. 277. 
other courts. Hence, judges at the religious courts, who have a university degree, must be qualified in applying those standards. The above discussion makes it clear that what are applied in the religious courts are procedural rules which, in some respects, might have nothing to do with Islamic procedural law. Moreover, the existing provisions do arguably put significant weight to the state laws concerning the courts' activities in making decisions.

\section{The Substantive Laws of the Religious Courts}

Before Marriage Law No 1/1974 was enacted, there were no unified substantive laws applied in the religious courts. The courts relied much on Islamic legal scholarship maintained in the classical figh literatures. A demand for a codification of Islamic law actually appeared in the post-independence. However, because there was much opposition from the majority of Muslims, it did not succeed. The proposed codification was seen a radical change to the established religious doctrines. ${ }^{17}$ The courts remained in reliance on Islamic legal authorities particularly the Shafi'i author-jurists' works. ${ }^{18}$ In 18 February 1958, the Bureau of Religious Justice in the Ministry of Religious Affairs delivered Surat Edaran No B/1/735 which instructed judges of the religious courts to seek guidance from 13 books of the Shafi $i$ i school in deciding cases. ${ }^{19}$

Since the promulgation of Marriage Law in 2 January 1974, the courts have been provided with the statutory provisions ascertaining the application of Islamic law as defined by the state. The reference to classical sources of Islamic law is possible as long as it does not contradict those provisions. In order to complement the statute in providing the unified applicable laws for the courts, the Compilation of Islamic Law (Kompilasi Hukum Islam) is laid down by the Presidential Instruction No 1/1991. This paper will discuss two sources of law for the religious courts; Marriage Law and the Compilation.

Marriage Law was enacted after bitter controversies on several provisions contained in the original bill. The statute to the large extent

\footnotetext{
17 See Lev, Islamic Courts, pp. 137-138.

18 These books included, for instance, Mughnì al-Muhtäj, al-Mahalli, I'änah al-Ṭälibin, alSharqäni 'alä al-Tahrìr, al-Iqnā' and Fath al-Qarïb. See, eg, the decisions of the religious courts in Notosusanto, Peradilan Agama Islam di Djawa dan Madura (Jogjakarta: n.p., 1953), pp. 82-181.

${ }^{19}$ See the General Elucidation of the Compilation of Islamic Law point 3.
} 
adopts the established doctrines in Islamic law regarding marital affairs. As Katz and Katz noted, 'this is the first time in Indonesia that substantive marriage law for Moslems has been codified by the state to any appreciable extent'. ${ }^{20}$ Through this new law, however, Islamic legal tradition of marriage was modified to accept "modern" interpretations of Islamic law. Moreover, it was forced to acknowledge the government's role in interpreting the Islamic tradition. ${ }^{21}$

Although the Islamic roots of the law are clear, one cannot deny the fact that this law was the result of a compromise among several elements of Indonesian society. More importantly it is the political product which provides the state definition of Islamic marriage law. The General Elucidation of Marriage Law indicates how the state ideology and legal politics constitute the foundations of the statute. It states that the statute accommodates the living legal traditions as well as the very principles embodied in Pancasila and the Constitution of 1945. In addition, it highlights certain legal policies underlying the law including the necessity of the registration of marriage, the principle of monogamy and the principle of making divorce difficult.

Marriage Law consists of 14 chapters and 67 articles. It lays down the provisions regarding foundations of marriage, its prerequisites and prevention, marriage contract, rights and responsibilities of husband and wife, marital property, dissolution of marriage, position of children, rights and responsibilities between parents and children, guardianship, parentage of children and marriage outside Indonesia.

In 1991, the government promulgated a new regulation concerning rules of law applicable in the religious courts. The Presidential Instruction No 1 of 1991 gave an order to the Minister of Religious Affairs to spread and apply the so-called Compilation of Islamic Law. The Minister then followed up this instruction with a decree (KMA) No 154 of 1991.22 The Compilation is, in fact, an Islamic Code for

${ }^{20}$ June S Katz and Ronald S Katz, "The New Indonesian Marriage Law: A Mirror of Indonesia's Political, Cultural and Legal Systems," The American Journal of Comparative Law, vol. 23 (1975): pp. 669-670.

${ }^{21}$ Mark Cammack, Lawrence A Young and Tim Heaton, "Legislating Social Change in an Islamic Society: Indonesia's Marriage Law," The American Journal of Comparative Law, vol. 44 (1996): p. 46.

22 On the historical account of the Compilation, see, eg, Departemen Agama RI, Instruksi Presiden RI Nomor 1 Tabun 1991 Kompilasi Hukum Islam di Indonesia (Jakarta: Direktorat Pembinaan Badan Peradilan Agama, 1998/1999), pp. 121-178; Ahmad Imam Mawardi, "The Political Backdrop of the Enactment of the Compilation of 
Indonesian Muslims; a code in which the idea behind it is arguably back to the Code of Majallah which governed most of the Muslim countries in the early of twentieth century. ${ }^{23}$ The Compilation becomes a legitimate source, though remains contested among constitutional theorists as well as judges of the Religious Courts, ${ }^{24}$ for the religious courts which provides certainty and uniformity in the application of Islamic law in Indonesia. ${ }^{25}$ As mentioned in the General Elucidation, the Compilation is made in order to provide a guidance of applicable laws for judges within the jurisdiction of the Religious Courts.

It might be suggested that the motive behind the introduction of the Compilation is religious because it would provide the religious courts with certain Islamic rules adopted from Islamic legal authorities. However, it seems that the political background and reasons dominate the law making. Yahya Harahap, one of the committee members of the Compilation, pointed out that there were at least four objectives operative in the law making process. ${ }^{26}$ First, by providing the source of reference or substantive law, it was seen a necessary pillar for religious justice. Second, it was aimed at promoting legal unification and certainty. Third, it was meant to strengthen ukhuwwah (brotherhood among Muslims) and also to diminish conflicts among Muslims (kbilafizyah). Finally, it was aimed at encouraging disputes settlement in formal institutions. It is clear, then, that the very objective of the

Islamic Laws in Indonesia," in Arskal Salim and Azyumardi Azra (eds), Shari'a and Politics in Modern Indonesia (Singapore: ISEAS, 2003), pp. 127-131; Euis Nurlaelawati, Modernization, Tradition and Identity: the Kompilasi Hukum Islam and Legal Practice in the Indonesian Religious Courts (Leiden: EJ Brill, 2010), pp. 80-89.

23 On the Majalla, see Norman Anderson, Law Reform in the Muslim World (London: University of London Athlone Press, 1976), pp. 51-52.

${ }^{24}$ On the contested authority of the KHI, see Amrullah Ahmad, et.al., Dimensi Hukum Islam dalam Sistem Hukum Nasional (Jakarta: GIP, 1996); Euis Nurlaelawati, Modernization, Tradition and Identity, Ch. III. Challenging the KHI's patriarchal standpoints, Government sponsored Team of Gender Mainstreaming produced what is called "the Counter Legal Draft of the KHI". However, after heated protests, the Government finally stepped down from continuing the project. See Marzuki Wahid, "Counter Legal Draft Kompilasi Hukum Islam (CLD-KHI) dalam Perspektif Politik Hukum di Indonesia" Paper presented at The 4th Annual Islamic Studies Postgraduate Conference, The University of Melbourne, 17-18 November 2008, pp. 48-68; Nurlaelawati, Modernization, Tradition and Identity, pp. 125-129.

${ }^{25}$ Cammack, “Indonesia’s 1989 Religious Judicature Act”, p. 165.

${ }^{26}$ See Mawardi, “The Political Backdrop”, p. 137. 
Compilation relates to the idea of providing the religious courts with substantive laws and, accordingly, establishing the legal unification and certainty in the country.

The Compilation consists of three books, marriage (Article 1-170), inheritance (Article 171-214) and wakaf (Article 215-229). In many places, state legislations and regulations are quoted as the legitimate source of reference. The Compilation reveals the character of the modern codifications. The codification is a salient feature of the modern state sovereignty which is established on the idea of a monopoly of law making authority. ${ }^{27}$ It symbolizes the state power in defining Islamic law. Islamic law is recognized to the point that it will not conflict with the national ideology and legal policies. Moreover, the nature of the Compilation itself indicates blatantly how the state control becomes possible particularly in the area of personal status. It might be true to name the Compilation merely as 'a bureaucratic handbook', as Hooker and Lindsey noted. ${ }^{28}$ This is because the notion of the application of Islamic law in the Compilation is subject to bureaucratic procedures. Its formulation, which is very simple statements and in accordance with the form of standard legislations, seems to make the courts greatly rely on it.

As mentioned above, Law on Religious Justice requires the religious courts' judges to greatly consider relevant statutory provisions and regulations in decision making. The discussion in this section also demonstrates that Marriage Law and the Compilation constitute substantive laws of the courts. The discussion suggests that the court judges will consider these regulations when dealing with cases before them. In what follows, this paper will examine the religious courts' decisions on inheritance. It attempts to answer the question of whether the courts' decisions greatly rely on Islamic sources - by using Islamic legal reasoning - or state regulations.

\section{The Religious Courts' Decisions and Legal Reasoning: The Case of Inheritance}

Inheritance law in Indonesia was linked to the struggles between religious and Indonesian identity, or the conflicts between the advocates of Shari'a implementation and the supporters of adat law.

27 See, e.g., Cammack, Lawrence A. Young and Tim Heaton, "Legislating Social Change", p. 53; Hallaq, "Juristic Authority vs State Power", p. 255.

${ }^{28}$ Hooker and Tim Lindsey, "Public Faces of Syari'ab", p. 278. 
Devoted Muslims would encourage the application of Islamic rules of inheritance (farä $i d$ ), while adat supporters encouraged the reference to local custom as a form of the adherence to indigenous identity. ${ }^{29}$ This struggle was particularly reflected in the religious courts' jurisdiction over inheritance. The courts' achievement to be legitimate in deciding inheritance cases was considered ideological. As Daniel S Lev pointed out, "the inheritance competence was regarded as ground won for Islam, in a critical historical social and political sense rather than merely a narrowly legal one." 30

From 1937 to 1989 inheritance had been no longer a jurisdiction of the religious courts in Java and Madura. Outside these islands, the courts continued to enjoy such jurisdiction. Although formally incompetent to decide inheritance cases, still, the courts in Java and Madura continued to do so. Inheritance problems on a large scale were brought to the courts. Judges after considering the problems and relevant Islamic doctrines gave legal opinions or fatwas. The format of fatwa seems to be the same as that of the courts' decision. ${ }^{31}$ With the enactment of Law on Religious justice, inheritance is included as one of the jurisdictions of all religious courts in the country. The courts now can resolve inheritance problems in a formal manner.

Before analyzing the courts' decisions on inheritance, we need to make clear the nature of the courts' decisions. The structure of decisions has not been the subject of significant changes since the Dutch period. The same format would also be found in general courts' decisions. ${ }^{32}$ Law on Religious Justice adds only a provision that the decision must be commenced with Bismillah. The decisions mainly contain the identity of plaintiffs and respondents or appellants and respondents, the issue of a case at hand (duduk perkara), legal considerations (menimbang or tentang hukumnya) and a decision (memutus or mengadili). The identity of parties before the court includes their age, religion, professional work and address. The issue of a case consists of

${ }^{29}$ Mark Cammack, "Islamic Inheritance in Indonesia: The Influence of Hazairin's Theory of Bilateral Inheritance" Australian Journal of Asian Law, vol. 4 (2002): p. 295.

${ }^{30}$ Lev, Islamic Courts, p. 198.

${ }^{31}$ Ibid., pp. 199-204.

32 For Java and Madura it refers to HIR (Herziene Inlandsch Reglement) Article 184 and RBg (Rechtsreglement Voor de Bintengewesten) Article 195 for outside Java and Madura. See, e.g., Riduan Syahrani, Himpunan Peraturan Hukum Acara Perdata Indonesia (Bandung: Alumni, 1991), p. 216, and p. 266. 
material facts, the plaintiff and defendant's arguments and, if the appellate court is concerned, the trial court's decision. Legal considerations generally include legal standing of the parties, the court's view of the material facts, its evaluation of the plaintiff and defendant's arguments and a reference to relevant regulations and/or Islamic literatures. Simple statements regarding the result of the case and costs of proceedings are also mentioned in this consideration. Finally, the result of a case is stated completely and clearly in the decision of the court.

The religious courts' decisions that will be discussed are the decisions on inheritance issued since the promulgation of Law on Religious Justice and the Compilation of Islamic Law. The decisions at hand generally deal with the determination of heirs, their legitimate portion, the joint marital property, the portion of adopted children and the status of a gift and a bequest. To find the courts' reasoning, the emphasis will be placed on the courts' legal considerations. The term "menimbang" (in consideration of) arguably shows the grounds of their decisions. As is also the case with the general courts, the first part of consideration deals with ascertaining the material facts and legal standing of both the plaintiff and defendant. The courts are, then, concerned with the evaluation of the parties' arguments and their own arguments and justification.

Considerations regarding relevant statutory provisions and regulations are determinative of the courts' decisions. It seems that the courts' reasoning is merely to apply those regulations in given facts. The courts' arguments are mainly about whether a claim is in accordance or conflict with relevant regulations. This approach is of the apparent characteristics of judicial reasoning in the Civil Law system. As Marryman has noted,

[t] he judge becomes a kind of expert clerk. He is presented with a fact situation to which a ready legislative response will be readily found in all except the extraordinary case. His function is merely to find the right legislative provision, couple it with the fact situation and bless the solution that is more or less automatically produced from the union. The whole process 
of judicial decision is made to fit into the formal syllogism of scholastic logic. ${ }^{33}$

I will provide three cases on the issue of inheritance that were adjudicated before the religious courts in various regions of the country. The courts' decisions on these cases reveal how they reason, deal with the law (legislations/regulations) and maintain Islamic sources.

In $H M$ Harun bin $H M$ Soleh and others $v$ Nurmalawati binti $H M A l$, the plaintiffs sued the defendant on the ground that the defendant had illegitimately controlled the deceased's ( $\mathrm{Hj}$ Mariyam binti $\mathrm{H}$ M Soleh) property. They argued that the defendant was not one of the deceased's heirs because she was an adopted child. The defendant in response argued that the property she currently controlled was a gift (bibah) from the deceased before she died. The plaintiffs challenged the validity of the gift because it was not in accordance with inheritance law in Islam (farä'id). The Religious Court of Palembang held that the plaintiffs' claims were not supported by evidence. As the gift was registered as the gift act (akta hibah) almost a year before the deceased died, the gift accordingly was a pure gift in accordance with Article 212 of the Compilation. This was also supported by the yurisprudensi of the Supreme Court. ${ }^{34}$ The plaintiffs then appealed to the Religious High Court of Palembang. ${ }^{35}$ As the Court affirmed the trial court's decision, they appealed to the Supreme Court. The Court allowed the appeal on the grounds that the accepted gift should not exceed one-third of the inherited property. The Court's decisions are based mainly on whether the previous courts had correctly applied and interpreted relevant law. Because the provisions in the Compilation (Article 210) were not properly applied, the Court decided to set aside the previous courts' decision. ${ }^{36}$

In the aforementioned case, the courts relied on the Compilation, although they interpreted it in different ways. The reference to Islamic sources was totally absent. The value of a gift in Islamic law is

\footnotetext{
33 John Henry Marryman, The Civil Law Tradition: An Introduction to the Legal Systems of Western Europe and Latin America, 2nd ed (Stanford, California: Stanford University Press, 1985), p. 36.

34 Putusan Pengadilan Agama Palembang No. 357/pdt.G/1996/PA.Plg.

35 Putusan Pengadilan Tinggi Agama Palembang No. 13/Pdt.G/1997/PTA.Plg.

36 Putusan Mabkamah Agung No. 29/K/AG/1998.
} 


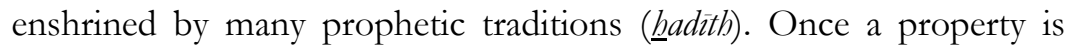
transferred as a gift to someone, it becomes under his or her possession. Regarding the total amount of the property allowed to be given as a gift, the majority of 'ulamā agree that one can donate all his property during his or her life. However, according to Muhammad ibn Hasan and other followers of the Hanafi School, someone who gives her whole property is mentally weak and for that reason her conducts to property must be interdicted. ${ }^{37}$ The courts' decisions clearly ignored these sources of reasoning. The courts considered only whether Article 212 of the Compilation, which stipulates that a gift cannot be annulled except a gift from a parent to their children, or Article 210, which limits the gift to one-third of the property, could be applied in this case. Similarly, there are many other cases decided by the religious courts solely on the basis of the legislations, in particular the Compilation.

In other cases, however, the religious courts refer to and cite Islamic sources. In Sapari bin Sartawi alias Tawi v Sapari alias Suwarno bin Darjan and another, the plaintiff sued the defendants on the grounds that because the plaintiff was the only child and heir of the deceased, he should share all the deceased's property. The plaintiff claimed that the defendants had controlled illegitimately the deceased's property. In their arguments the defendants rejected sharing the property because the plaintiff was not the deceased's child. They argued that the deceased only had a wife, Sarmi, and never had the second wife who was allegedly the plaintiff's mother. The Religious Court of Kisaran held that on the basis of agreed evidence the court recognized that the plaintiff was the deceased's child. In dealing with evidence, the court referred to many provisions including the RBg of Article 308(1) and 309 which governed the value of witness and Article 180 which governed observation on a given object of disputes and Law No 5/1960. In the light of Article 174(1) of the Compilation, the court then decided that the plaintiff was the deceased's heir. And, because he was the only heir of the deceased, the plaintiff took all the deceased's property ('asaabah bi nafsib). To support this conclusion, the court

\footnotetext{
${ }^{37}$ See, e.g., Sayyid Sābiq, Fiqh al-Sunnah, 4th ed. (Beirut: Dār al- Fikr, 1983), vol. 3, p. 392; Wahbah al-Zuhailī, Mawsü'ah al-Fiqh al-Islämì wa al-Qậayā al-Mu'așirah (Damascus: Dār al-Fikr, 2012), vol. 4, pp. 697-699.
} 
referred to the authority of $i j m \bar{a}$ ' as mentioned in Ibn Rusyd's book, Bidāyah al-Mujtabid. ${ }^{38}$

The defendants appealed to the Religious High Court of Medan. The court affirmed the trial court's decision and dismissed the appeal. In its considerations, this appellate court rejected the grounds of the defendants' (here the appellants') arguments and proposed evidence by reference to Law on Religious Justice and yurisprudensi. The appellants' objection to the existence of the deceased's marriage with the plaintiff's (here the defendant's) mother was regarded ill-founded. This was because, among other things, the statutes and regulations concerning marriage were not retrospective. To prove the existence of marriage and a child, the court only needed the available evidence as stipulated in the Shafici book, I'ánah al-talibin. ${ }^{39}$ The appellant then appealed to the Supreme Court. The Court allowed the appeal. The Court's considerations are about misinterpretation and misapplication of the relevant statutes and regulations. ${ }^{40}$

The above-mentioned case was an action for a legitimate division of inheritance property. To decide whether the plaintiff could be allocated the assigned shares, the court initially held that the plaintiff was actually the deceased's child. Having acknowledged that the plaintiff was the only heir of the deceased, the court then decided that he would own all the deceased's property. The court's decision here raised two legal issues, namely the evidences of the origins of a child and his allocated portion. Regarding the first, the trial court relied on the RBg while the High Court referred to the authority of the Shafi $i$ school. This reference by the High Court is made on the basis of the principle of non-retroactivity of the relevant regulations. In this sense, the court's consideration actually demonstrates how the court would be bound by these regulations prospectively. The issue of evidence is also a subject matter in Islamic legal literatures. In general, there are many kinds of evidence in Islamic figh: testimony, confession, oath, qasämah and circumstantial evidence (qaräin). Muslim jurists have different opinions regarding the value of them. ${ }^{41}$ As for the claim for a

\footnotetext{
38 Putusan Pengadilan Agama Kisaran No. 147/Pdt.G/1994/PA-Kis.

39 Putusan Pengadilan Tinggi Agama Medan No. 34/Pdt.G/1995/PTA-Mdn.

40 Putusan Mabkamah Agung No. 216 K/AG/1996.

41 See 'Abd al-Karīm Zaydān, Niżām al-Qaḍā', pp. 155-242; Wahbah al-Zuhailī, Mawsū'ah al-Fiqh al-Islämi, vol. 6, pp. 474-557.
} 
right of inheritance, it is necessary to prove that the plaintiff has the blood relationship (nasab) with the deceased. In doing so, the court relies on the availability of the above mentioned evidence provided to the court. The second issue was dealt by the trial court on the basis of the Compilation (Article 174) and the consensus (ijmāa). Apart from a daughter, a son is a residuary heir in his own right ('asabah bi nafsib). He could inherit all the deceased's property when he stands alone. This is clear from the court's reference to the consensus. Islamic legal theory places the authority of consensus after the Qur'an and Sunna.

In this case, the court's decision underlines the close correspondence between the legislations and the Islamic sources. Many decisions held by the religious courts in Indonesia take this model of reasoning. It seems not enough for the courts to refer only to the legislations. For the courts, the authority of the decisions would be strengthened by their reference to the Islamic sources. The reliance on the legislations as well as the Islamic sources indicates the twin character of the courts. They are part of the state organs which has to apply the state law. At the same time, the courts are Islamic institutions which are obliged to enforce Islamic law. Therefore, for the courts the reference to Islamic sources becomes more persuasive.

In the third case, Madli bin Aswan and others v Hj Khoiriyah, the religious court also took into consideration Islamic sources as well as legislations. In this case, the plaintiffs claimed that they shared the deceased's property which was under the control of the defendant. They asked the court to include them as the deceased's heirs and allocated each of them the assigned shares. Because it was a joint property between the deceased and the defendant, they claimed onehalf of the property. In addition, because the defendant had controlled all the joint property, accordingly she had acted against the law. The defendant contended that the action should be dismissed because there were many heirs who were not included in the plaintiffs' complaint, such as representative heirs (abli waris pengganti) and an adopted child. Moreover, the alleged property in fact had been sold for medical maintenance of the deceased.

The Religious Court of Pemalang held that the plaintiffs were entitled to legitimate portions of the property. The court argued that the problem of representative heirs was based on personal reasoning (ijtibäd). There was no consensus among Muslim scholars on this issue. It is important to consider the court's reasons for not acknowledging 
the existence of the representative heirs. Having stated that local custom as well as local ulama did not recognize them, the court pointed out that if this case was maintained in accordance with this opinion, public benefits (kemashlabatan umat) and legal certainty would be achieved'. The court interpreted Article 185 of the Compilation, which explicitly recognized the existence of substitute heirs, as not pointing to the mandatory status of these heirs' shares. In addition, the court considered that the adopted child according to the Compilation was not an issue of inheritance but of bequest. Having accepted the plaintiffs' complaint, the court decided that all the property in dispute was jointly owned and should be divided accordingly. The Qur'an anNisa 12 and 176 were quoted to highlight each share. ${ }^{42}$ Having not been satisfied with the result, the defendant appealed to the Religious High Court of Central Java (Semarang). The High Court decided to allow the appeal. According to the court, the petitum proposed by the plaintiffs was not valid. The complaint was also held unclear or obscures (obscuur libel). Accordingly, the plaintiffs' claim could not be accepted. ${ }^{43}$

The High Court's reasoning in the above case seems to be too procedural, judging the complaint merely on the basis of its fulfillment to the required procedures and administration. The grounds of the court's decision are legal concepts unknown in Islamic law. The trial court interestingly appealed to the notion of local benefits and public interests (maslabab) to annul the portion of representative heirs. In doing so, the court interpreted the provisions of the Compilation in a different way. Regarding the adopted child, the court referred only to the Compilation. This very fact demonstrates the significance of the Compilation in the judgment. It seems that the Compilation will always be considered even when the court gives unprecedented judgment. The appeal to the idea of public benefits and legal certainty aims to set a ground for the court to take another version of interpretation which deems the allocation of shares to the representative heirs as not compulsory. In fact, traditional Islamic law does not recognize the concept of representative heirs. Neither divine texts (nas) nor ulama's opinions support it. This is a new formulation (ijtihād) introduced by Hazairin which is currently acknowledged by the state. As is also the

42 Putusan Pengadilan Agama Pemalang No. 1470/Pdt.G/1996/PA.Pml

${ }^{43}$ Putusan Pengadilan Tinggi Agama Semarang No. 70/Pdt.G/1997/PTA.Smg 
case with every ijtibäd, the value of representative heirs is not absolute. Public benefits might provide a sound ground for admitting or rejecting this concept. The court's reference to this notion is unfortunately not elaborate. There is no further explanation, for instance, of why this authority is taken into consideration and how it should be preferred to other authorities.

\section{The Practice of Islamic Legal Reasoning}

The above-mentioned case examples inform the readers about the practice of judicial reasoning in the religious courts particularly since the promulgation of the Compilation. It seems that the reasoning employed is generally legalistic. The task of the courts is merely to apply the law in given cases. Emphasis is much given to procedural matters. From those cases, however, we have three different models or approaches of judicial reasoning employed by the religious courts. First, many religious courts' decisions provide only the legislations particularly the Compilation as the sole source of reasoning. The legislations are to be found by the judges and then applied in a given case. The process of reasoning follows formal syllogism or deductive logics. Hooker and Lindsey have demonstrated the courts' dependence on state laws without much elaboration and the way the courts come to judgments. They pointed out,

[t]he reported yurisprudensi is sparse and when available minimalist, in the sense that, in most cases, decisions are given in a bare form-sometimes only one or two pages-with little concern expressed to explain the reasoning. The only constant feature of Religious Court decisions is the use of Pancasila and, to a lesser extent, the Kompilasi, as basic reference points but these tell us almost nothing about legal reasoning. ${ }^{44}$

Secondly, the courts employ and refer to the Islamic sources in combination with the legislations. Still, it shows same implications.. The use of the Islamic sources is complementary. As indicated above, this dual reference might suggest the courts' needs to legitimize their decisions on the basis of the state law as well as Islamic law. However, in using the Islamic sources, they remain faithful to deductive logics; they maintain these sources as in upholding legislations.

${ }^{44}$ Hooker and Tim Lindsey, "Public Faces of Syariab”, p. 276. 
Those two approaches employed by the religious courts reveal the character of judicial reasoning embedded in the courts. It has been argued that since the medieval Islam, the judges (qädi's) were no longer mujtahids. They should be affiliated to one school (madhhab) recognized by the rulers and Muslim community. In addition, there was a widespread belief in Muslim community that the task of the judges was merely to apply the law as bureaucrats applied the administrative law on the basis of the established school and legal opinions of muftis. ${ }^{45}$ In Islamic point of view, what these judges usually do is to practice taqlid, meaning to adhere to the well-established doctrines of Islamic law without much consideration of the basis (usini) and evidences (adillah) out of which legal rules are derived.

Another explanation might come from the fact that since the establishment of modern nation-state the authority of law making has been taken up by the state. It alone is sovereign in making law. The state examines this authority by making codifications. The professional lawyers provide with their methods of interpretation, how these codifications are to be applied in given situations. The Indonesian legal system reflects this fact. Inherited from the Dutch legal tradition, Indonesian courts are obliged to apply the law according to legitimate methods of judicial reasoning. The religious courts accordingly should decide cases before the court on the basis of existing laws provided by the state and judicial methods which are commonly and legitimately used in all courts. The role of judges is to find a true meaning of law, statute. Courts are bound by a code, statute. Legislative acts, therefore, constitute the very source of judicial reasoning in the Civil Law world. ${ }^{46}$ As Pierre Legrand argues, all judicial decisions must adhere to the "law of the text"; "this text is experienced as sacred". 47

Using the Islamic terminology, the judges are muqallids (people who perform taqlid), not to the school doctrines but to the state-defined law. As Netherlands and then Indonesia belong to Civil Law system, the judges' function as indicated by Merryman is merely to find the right provisions by using syllogistic methods.

\footnotetext{
${ }^{45}$ Hallaq, Authority, Continuity and Change, p. 76.

46 René David and John E. C. Brierley, Major Legal Systems in the World Today: An Introduction to the Comparative Study of Law, $3^{\text {rd }}$ ed. (London: Stevens, 1985), pp. 134-137.

47 Pierre Legrand, "Review: Antiqui Juris Civilis Fabulas," The University of Toronto Law Journal, vol. 45 (1995): p. 311.
} 
In the final approach, the courts may apply Islamic legal reasoning with the emphasis on the objectives of Islamic law (maquasid al-sharía) ${ }^{48}$ The trial court's reasoning in the last case (Madli bin Aswan and others $v$ $\mathrm{Hj}$ Khoiriyah) is indicative of the controversial nature of the Compilation in the beginning of its promulgation. For some ulama, the norms contained in this "quasi-law" are unacceptable according to the conventional jurisprudence. In considering the Compilation, the court tried to position it in the framework of Islamic legal theory (usūu alfiqb). It exploited the key concept in the realm of the objectives of Shari'a, namely maslahat, in its interpretation of the norm of representative heirs. Here, Islamic legal reasoning might be employed but in very brief and straightforward.

In his analysis of the Religious Court of Tasikmalaya on the case of Warsib \& Warnah v. Iim Rohimah, John R. Bowen demonstrated the court's appeal to Islamic legal reasoning. He suggested that in that case the Court made reference to al-Qur'an 4:176 in support of its argument on the rights of heirs and, then, provided Islamic basis of the gift rulings in the Compilation. However, the basis of which the limitation of gifts rests is mainly on Islamic authority of bequests not gifts. Bowen then argued that "the reasoning process involves an analogy, a form of qiyass, even though the term 'qiyas' is never used, nor an explicit analogy ever drawn." 49 Here, the Court might apply qiyass, but in indirect fashion and, consequently, without conforming its requirements. In justifying the Compilation rule on that matter, the Court also argued on the basis of maqāsid that "limiting gifts preserves the welfare of the heirs and benefits society by reducing begging". ${ }^{50}$ Although the reference to a method in Islamic legal reasoning is made,

\footnotetext{
48 The concept of Maqāsid al-Sharía has been developed since centuries ago as part of Islamic legal theories. Its discussion is placed under the subject al-maslabat al-mursalab (the unrestricted interest). In the modern context, however, it becomes a new discipline representing the methodology and philosophy of Islamic law. See Jasser Auda, Maqasid al-Shariah as Philosophy of Islamic Law: A Systems Approach (London \& Washington: IIIT, 2007). In this paper, I use maqäsid as a methodology of Islamic legal reasoning which includes methods of qiyäs, istihssän, istișläh and others. See, e.g., Satria Effendi M. Zein, Ushul Fiqh (Jakarta: Kencana, 2008), pp. 233-238.

49 John R. Bowen, Islam, Law and Equality in Indonesia: an Anthropology of Public Reasoning (Cambridge: Cambridge University Press, 2003), p. 137 (emphasis is mine).

${ }^{50}$ John R. Bowen, Islam, Law and Equality in Indonesia, pp. 139-140.
} 
the decision suffers from the clear-cut fashion of reasoning for its lack of reference to and analysis on Islamic sources regarding gifts.

Satria Effendi has clearly demonstrated how the courts' decisions are far from being satisfactory in terms of the Islamic legal point of view. In his analysis on different decisions made by the Religious Court of Mataram and the Supreme Court regarding the division of inheritance property and determination of legitimate heirs, Effendi examined that the decisions of both the Religious Court and the Supreme Court have made reference to the different views in Islamic legal scholarship; the Religious Court indirectly refer to the view of the majority of jurist, but the Supreme Court relied on the opinion of Ibn 'Abbas on the matter. However, they failed to provide reasons why they chose one view and discounted the other. ${ }^{51}$ What they did is merely to cite those views. They ignored the basis on which these views were formulated. This straightforward and simple reasoning is also evident in the Supreme Court's decision on the share allocated to the deceased's widow who was non-Muslim. ${ }^{52}$ Although the widow was not regarded as the deceased's heir, the Court concluded that a certain part of the property should be assigned to her as wasiyyah wäjibah (mandatory bequest). The Court's standpoint was based mainly by the Previous Court's relevant decision (Yurisprudensi) and quoting the authority of Yūsuf al-Qaradāīìi. Here, no elaborative arguments, by employing Islamic legal reasoning, were given as to why the Court took that position.

\section{Conclusion}

There are likely many similarities between religious and civil courts. With regard to procedural rules the religious courts rely on the general court procedures. Accordingly, there is no significant difference between them in the proceedings, grounds of judicial reasoning and the structure of decisions. The applicable substantive laws in the religious courts are mainly Marriage Law, the Compilation of Islamic Law and unwritten laws, which might be read as adat and unwritten Islamic law. Although both Marriage Law and the Compilation are mostly derived

51 Satria Effendi M. Zein, Problematika Hukum Keluarga Islam Kontemporer: Analisis Yurisprudensi dengan Pendekatan Ushuliyah, (Jakarta: Kencana, 2004), pp. 293-306.

52 Putusan Mabkamah Agung No. 16 K/AG/2010. Assigning washiyyah wajibah to nonMuslim relatives constitutes the Supreme Court's precedent (No. 368 K/AG/1995 and No. $51 \mathrm{~K} / \mathrm{AG} / 1999)$. 
from Islamic law, some provisions indicate a significant departure from the traditional interpretation. In addition, as codifications these regulations greatly reflect the state policies. The notion of Islamic law as the courts' substantive law has turned out to be the state-defined law.

The structure of the courts' decisions is not something unique. The very concept underlying the judicial decision making in the courts is likely to be found in most Civil Law courts; judges are merely to apply the regulations in given cases by using the syllogistic method of reasoning.

I have argued that the judges of the religious courts generally applied state laws using judicial methods which are common with other Indonesian courts. So, it can be concluded that there is no significance reference to Islamic law other than the stipulated and codified in the state laws such as the compilation. Even if there is a reference to the classical Islamic law, the court position it merely as a support to their decision. Moreover, the application are very simple and straightforward fashion.]

\section{References}

\section{Books and Articles}

Ahmad, Amrullah, et.al. Dimensi Hukum Islam dalam Sistem Hukum Nasional. Jakarta: GIP, 1996.

Anderson, Norman. Law Reform in the Muslim World. London: University of London Athlone Press, 1976.

Auda, Jasser. Maqasid al-Shariah as Philosophy of Islamic Law: A Systems Approach. London \& Washington: IIIT, 2007.

Bowen, John R. Islam, Law and Equality in Indonesia: an Anthropology of Public Reasoning. Cambridge: Cambridge University Press, 2003.

Cammack, Mark, Lawrence A. Young and Tim Heaton. "Legislating Social Change in an Islamic Society: Indonesia's Marriage Law." The American Journal of Comparative Law, vol. 44 (1996).

Cammack, Mark. "Indonesia's 1989 Religious Judicature Act: Islamization of Indonesia or Indonesianization of Islam?" Indonesia, vol. 63 (1997). 
. "Islamic Inheritance in Indonesia: The Influence of Hazairin's Theory of Bilateral Inheritance." Australian Journal of Asian Law, vol. 4 (2002).

--. "Islamic Law in Indonesia's New Order." The International and Comparative Law Quarterly, vol. 38 (1989).

David, René and John E. C. Brierley. Major Legal Systems in the World Today: An Introduction to the Comparative Study of Law. $3^{\text {rd }}$ ed. London: Stevens, 1985.

Departemen Agama RI. Instruksi Presiden RI Nomor 1 Tabun 1991 Kompilasi Hukum Islam di Indonesia. Jakarta: Direktorat Pembinaan Badan Peradilan Agama, 1998/1999.

Hallaq, Wael B. "Juristic Authority vs State Power: The Legal Crises of Modern Islam.” Journal of Law and Religion, vol. 19 (2003-2004).

--------. "Was the Gate of Ijtihad Closed?." International Journal of Middle East Studies, vol. 16, no. 1 (1984).

-----. Authority, Continuity and Change in Islamic Law. Cambridge: Cambridge University Press, 2001.

Hisyam, Muhammad. Caught between Three Fires: the Javanese Penghulu under the Dutch Colonial Administration 1882-1942. Jakarta: INIS, 2001.

Hooker, M. B. and Tim Lindsey. "Public Faces of Syariah in Contemporary Indonesia: Towards a National Mą̧ab?." Australian Journal of Asian Law, vol. 4 (2002).

Hooker, M. B. Islamic Law in South-East Asia. Kuala Lumpur: Harvard University Press, 1984.

Kamali, Mohammad Hashim. Principles of Islamic Jurisprudence. Revised ed. Cambridge: Cambridge Islamic Text Society, 1991.

-------. Shari'ah Law: an Introduction. Oxford: Oneworld Publications, 2008.

Katz, June S. and Ronald S. Katz. "The New Indonesian Marriage Law: A Mirror of Indonesia's Political, Cultural and Legal Systems." The American Journal of Comparative Law, vol. 23 (1975).

Legrand, Pierre. "Review: Antiqui Juris Civilis Fabulas." The University of Toronto Law Journal, vol. 45 (1995). 
Lev, Daniel S. Islamic Courts in Indonesia: A Study in the Political Bases of Legal Institutions. Berkeley: University of California Press, 1972.

Makdisi, John. "Formal Rationality in Islamic Law and the Common Law." Cleveland State Law Review, vol. 34 (1985-1986).

Marryman, John Henry. The Civil Law Tradition: An Introduction to the Legal Systems of Western Europe and Latin America. $2^{\text {nd }}$ ed. Stanford, California: Stanford University Press, 1985.

Māwardī, Abū al-Hasan al-. al-Ahkeàm al-Sultāniyyah wa al-Wilāyāt alDiniyyah. Beirut: Dār al-Fikr, 1996.

Mawardi, Ahmad Imam. "The Political Backdrop of the Enactment of the Compilation of Islamic Laws in Indonesia." in Arskal Salim and Azyumardi Azra (eds). Shari'a and Politics in Modern Indonesia. Singapore: ISEAS, 2003.

Mayer, Ann Elizabeth. "Islam and the State." Cardozo Law Review, vol. 12 (1990-1991).

Notosusanto. Peradilan Agama Islam di Djawa dan Madura. Jogjakarta: n.p., 1953.

Nurlaelawati, Euis. Modernization, Tradition and Identity: the Kompilasi Hukum Islam and Legal Practice in the Indonesian Religious Courts. Leiden: EJ Brill, 2010.

Sābiq, Sayyid. Figh al-Sunnah. 4th ed. Vol. 3. Beirut: Dār al- Fikr, 1983.

Shaukānī, Muḥammad ibn 'Alī ibn Muḥammad al-. Irshād al-Fuhūl ilā Tặqiq al-Haqq min 'Ilm al-Uṣûl. Vol. 2. Beirut: Dār al-Kutub al'Ilmiyyah, 1999.

Syahrani, Riduan. Himpunan Peraturan Hukum Acara Perdata Indonesia. Bandung: Alumni, 1991.

Wahid, Marzuki. "Counter Legal Draft Kompilasi Hukum Islam (CLDKHI) dalam Perspektif Politik Hukum di Indonesia." Paper presented at The 4th Annual Islamic Studies Postgraduate Conference, The University of Melbourne, 17-18 November 2008.

Weiss, Bernard. "Interpretation in Islamic Law: The Theory of Ijtihäd." The American Journal of Comparative Law, vol. 26, no. 2 (19901991). 
Zarqā', Mushṭafā Aḥmad al-. al-Madkhal al-Fiqh al-'Āmm. Vol. 1. Damascus: Dār al-Qalam, 1998.

Zaydān, 'Abd al-Karīm. Nizām al-Qậā' fì al-Isläm. $2^{\text {nd }}$ ed. Beirut: Mu'assasah al-Risālah, 1989.

Zein, Satria Effendi M. Problematika Hukum Keluarga Islam Kontemporer: Analisis Yurisprudensi dengan Pendekatan Ushuliyah. Jakarta: Kencana, 2004.

\section{-------. Ushul Fiqh. Jakarta: Kencana, 2008.}

Zuhailī, Wahbah al-. Mawsüah al-Figh al-Islämi wa al-Qaḍyà alMu'așirah. Vol. 4. Damascus: Dār al-Fikr, 2012.

\section{Religious Courts' Decisions}

Putusan Pengadilan Agama Palembang No. 357/pdt.G/1996/PA.Plg.

Putusan Pengadilan Tinggi Agama Palembang No. 13/Pdt.G/1997/PTA.Plg.

Putusan Mabkamah Agung No. 29/K/AG/1998.

Putusan Pengadilan Agama Kisaran No. 147/Pdt.G/1994/PA-Kis.

Putusan Pengadilan Tinggi Agama Medan No. 34/Pdt.G/1995/PTA-Mdn.

Putusan Mabkamah Agung No. 216 K/AG/1996.

Putusan Pengadilan Agama Pemalang No. 1470/Pdt.G/1996/PA.Pml

Putusan Pengadilan Tinggi Agama Semarang No. 70/Pdt.G/1997/PTA.Smg

Putusan Mabkamah Agung No. 16 K/AG/2010. 